\title{
PERAN BANK SAMPAH DALAM MENINGKATKAN PENDAPATAN MASYARAKAT DENGAN MENYULAP SAMPAH MENJADI RUPIAH PADA BANK SAMPAH SRI REJEKI
}

\author{
Syamsul Mu'arif, Yulianto, Suciati Muanifah, \\ Yenni Cahyani, Muhammad Ridwan \\ Universitas Pamulang \\ Email:dosen02286@unpam.ac.id
}

\begin{abstract}
The waste sorting and utilization program has become something new and efforts to reduce waste generated by households have recently been campaigned intensively. South Tangerang City, which is a new area resulting from the expansion of Tangerang Regency, has also participated in this program, especially in the sub-district of Benda Baru, South Tangerang, more specifically in the Serua Permai housing area. There was a group of residents who formed a Waste Bank which was named BANK SAMPAH SRI REJEKI. The main problem faced by this waste bank is that the efforts to manage waste effectively and efficiently are not maximized, so that a new method or method is needed that can solve this problem, based on this, we propose a $3 R$-based waste management method (reduce, reuse). , recycle) in order to maximize waste management so as to reduce waste that is wasted in landfills (TPA). The decision to make this method begins with the results of field studies and interactions with the management of the Sri Rejeki Waste Bank and with its members, where in carrying out the activities of the waste bank they are still constrained in determining the appropriate method so that the resulting waste can be minimized. The output generated by this program is knowledge related to effective and efficient waste management methods or methods so as to increase the expertise of waste bank administrators and members in managing waste before or after the occurrence of waste. As for the parties who will get counseling regarding the $3 R$-based waste management method are the management and members of the Sri Rejeki Waste Bank, whose members are the majority of housewives, the role of these housewives is very important in efforts to reduce waste starting from the source, every time. day they produce garbage from every household activity. Realization The solution to the problem is by carrying out integrated counseling with the $3 R$-based waste management method by conducting online seminars or counseling, this is done because it is not possible to conduct direct counseling as a result of the Covid-19 pandemic. With the program, it is hoped that it will be able to solve the problems that exist in the Sri Rejeki waste bank and also be able to help the management and members of the waste bank in an effort to maximize $3 R$-based waste management, so that the role of Sri Rejeki's waste bank in efforts to overcome waste problems can continue to increase with the existence of this program. innovation from waste management based on efforts to reduce waste from its source, reuse of used goods into other forms that can be used and recycle waste that
\end{abstract}


really cannot be reused according to the criteria and groups of waste, so that in the end it will reduce the volume of waste which is dumped into the TPA.

Keywords: Reduce, Reuse, Recycle

\begin{abstract}
Abstrak
Program pemilahan dan pemanfaatan sampah menjadi sesuatu yang baru dan upaya mengurangi sampah yang dihasilkan rumha tangga akhir-akhir ini gencar di kampanyekan. Kota Tangerang Selatan yang merupakan wilayah baru hasil dari pemekaran Kabupaten Tangerang juga turut serta dalam program ini khususnya di kecamatan Benda Baru Tangerang Selatan, lebih spesifik berada di lingkungan perumahan Serua Permai. Disana terdapat kelompok warga yang membentuk Bank Sampah yang diberi nama BANK SAMPAH SRI REJEKI. Persoalan utama yang dihadapi oleh bank sampah ini adalah belum maksimalnya upaya pengelolaan sampah secara efektif dan efisien, sehingga diperlukan suatu metode atau cara baru yang dapat menyelesaikan masalah tersebut, berdasarkan pada hal tersebut maka kami mengajukan suatu metode pengelolaan sampah yang berbasis 3R (reduce, reuse, recycle) guna memaksimalkan pengelolaan sampah sehingga mampu mereduksi sampah yang terbuang pada tempat pembuangan akhir (TPA). Keputusan pengambilan metode tersebut diawali dari hasil studi lapangan dan interaksi dengan pengurus Bank Sampah Sri Rejeki maupun dengan para anggotanya, dimana didalam menjalankan aktifitas bank sampah mereka masih terkendala dalam hal penentuan metode yang tepat agar sampah yang dihasilkan dapat seminimal mungkin. Luaran yang dihasilkan oleh program ini adalah pengetahuan terkait dengan metode atau cara pengelolaan sampah yang efektif dan efisien sehingga mampu meningkatkan keahlian para pengurus dan anggota bank sampah dalam mengelola sampah baik sebelum atau sesudah terjadinya sampah. Adapun para pihak yang akan mendapatkan penyuluhan terkait dengan metode pengelolaan sampah berbasis 3R adalah para pengurus dan anggota Bank Sampah Sri Rejeki, yang anggaotanya mayoritas para ibu rumah tangga, peranan ibu-ibu rumah tangga ini sangatlah penting dalam upaya pengurangan sampah mulai dari sumbernya, setiap hari mereka menghasilkan sampah dari setiap aktifitas rumah tangganya. Realisasi Pemecahan permasalahan adalah dengan cara melakukan penyuluhan terakit dengan metode pengelolaan sampah berbasis $3 \mathrm{R}$ dengan jalan melakukan seminar atau penyuluhan secara daring, hal ini dilakukan karena tidak memungkinkan untuk melakukan penyuluhan secara langsung akibat dari adanya pandemic covid-19. Dengan adanya program diharapkan mampu untuk mengatasi permasalahan yang ada pada bank sampah Sri Rejeki dan juga mampu membantu para pengurus maupun anggota bank sampah dalam upaya maksimalisai pengelolaan sampah berbasis $3 \mathrm{R}$, sehingga selanjutnya peranan bank sampah Sri Rejeki dalam upaya mengatasi permasalahan sampah dapat terus meningkat dengan adanya inovasi dari pengelolaan sampah yang berdasarkan pada upaya pengurangan sampah dari sumbernya, penggunaan kembali barang bekas menjadi bentuk lain yang dapat
\end{abstract}


dimanfaatkan dan mendaur ulang sampah yang benar-benar tidak bisa di manfaatkan lagi sesuai dengan kriteria dan kelompok sampah, sehingga pada akhirnya akan mengurangi volume sampah yang dibuang ke TPA.

\section{Kata Kunci: Reduce, Reuse, Recycle}

\section{A. PENDAHULUAN}

Pertambahan jumlah penduduk, perubahan pola konsumsi, dan gaya hidup masyarakat telah meningkatkan jumlah timbulan sampah, jenis, dan keberagaman karakteristik sampah. Meningkatnya daya beli masyarakat terhadap berbagai jenis bahan pokok dan hasil teknologi serta meningkatnya usaha atau kegiatan penunjang pertumbuhan ekonomi suatu daerah juga memberikan kontribusi yang besar terhadap kuantitas dan kualitas sampah yang dihasilkan. Meningkatnya volume timbulan sampah memerlukan pengelolaan. Pengelolaan sampah yang tidak mempergunakan metode dan teknik pengelolaan sampah yang ramah lingkungan selain akan dapat menimbulkan dampak negatif terhadap kesehatan juga akan sangat mengganggu kelestarian fungsi lingkungan baik lingkungam pemukiman, hutan, persawahan, sungai dan lautan.

Ada banyak sekali alasan mengapa daur ulang limbah harus dilakukan. Pertama adalah untuk konservasi sumber daya. Daur ulang ikut membantu mengkonservasi sumber daya alam dengan mengurangi kebutuhan akan material baru. Kedua, untuk konservasi energi. Daur ulang menyelamatkan energi dengan cara mengurangi kebutuhan akan material baru yang biasanya membutuhkan lebih banyak energi dibandingkan dengan melakukan proses daur ulang. Ketiga, untuk pengurangan polusi. Daur ulang mengurangi polusi karena daur ulang menghasilkan produk baru yang lebih sedikit menghasilkan polusi. Keempat, untuk konservasi lahan. Dengan melakukan daur ulang terhadap berbagai macam material, akan mengurangi sampah yang harus dibuang. Maka lahan yang dibutuhkan untuk menimbun sampah-sampah akan berkurang. Kelima, untuk alasan ekonomi. Produk daur ulang akan menambah pendapatan nasional yang berimbas pada kesejahteraan bangsa.

Bank Sampah Sri Rejeki, yang beralamat di Perumahan Sarua Permai Jl. Borobudur 1 C 26 No. 5 RT. 01 RW. 04 Kelurahan Benda Baru Kecamatan Pamulang Kota Tangerang Selatan dapat memanfaatkan sampah rumah tangga berupa sampah organik menjadi kompos dan sampah anorganik menjadi produk kerajinan seperti tas, dompet, taplak meja, bunga hias dan lain-lain. Cara tersebut dinilai efektif untuk menangani sampah rumah tangga dan mendongkrak pendapatan masyarakat sekitar.

Sasaran pengabdian masyarakat ini tentu saja adalah para warga di Perumahan Sarua Permai Jl. Borobudur 1 C 26 No. 5 RT. 01 RW. 04 Kelurahan Benda Baru Kecamatan Pamulang Kota Tangerang Selatan dan pada khususnya adalah pengurus dan anggota Bank Sampah Sri Rejeki, Pelaksanaan PKM ini sudah tentu melibatkan institusi pemerintahan seperti Pengurus RT, Pengurus RW dan Pengurus Bank Sampah untuk Wilayah kecamatan yang merupakan wadah yang membantu serta mendukung kepengurusan Bank sampah di Sri Rejeki ini. Dengan harapan dengan terlibatnya berbagai pihak ini akan menyebarkan lebih luas lagi kepada pengurus - pengurus lainnya yang tidak dapat menghadiri acara pelatihan ini.

Dari hasil program Pengabdian Kepada Masyarakat Dosen Universitas Pamulang diharapkan berdampak dengan adanya kegiatan ini peran bank sampah akan lebih berarti dalam upaya meningkatkan kesejahteraan masyarakat dengan mengadakan kegiatan pemberdayaan ekonomi, kegiatan pemberdayaan ekonomi yang dilakukkan adalah dengan 
menerapkan Prinsip 3R (Reduce, Reuse, Recycle) diantaranya kerajinan sampah anorganik dan mengubah sampah organik menjadi pupuk yang bisa berpengaruh terhadap pendapatan masyarakat.

\section{B. METODE PELAKSANAAN KEGIATAN}

Pelaksanaan program kegiatan Pengabdian Kepada Masyarakat (PKM) ini melalui beberapa tahapan yang telah dilaksanakan, antara lain dapat digambarkan dalam alur berikut:

1. Persiapan Kegiatan

a. Perijinan

Proses perijinan dimulai dengan meminta ijin ketua RW dan ketua RT setempat

b. Pengamatan Kondisi Masyarakat

Setelah memperoleh ijin dari pihak terkait, dilakukan proses survei dan wawancara untuk mendapatkan informasi mengenai masalah yang ada.

c. Analisis Program

Terdapat beberapa informasi permasalahan yang ada pada bank sampah Sri Rejeki, namun masalah yang paling menarik adalah terkait pengelolaan yang belum maksimal dan atau sistem manajemen bank sampah yang masih kurang baik, dari telaah tersebut Tim membuat kesimpulan serta cara yang memudahkan pengurus bank sampah untuk terus mengevaluasi serta mengembangkan Bank Sampah tersebut.

d. Perencanaan dan Pembuatan Program

Program yang digunakan untuk mengatasi masalah pengolahan dan pengelolaan sampah dengan prinsip 3R (Reduce, Reuse, Recycle).

2. Pelaksanaan Kegiatan

a. Seminar Program

Seminar adalah suatu bentuk komunikasi verbal yang bersifat ilmiah untuk membahas suatu masalah yang menyangkut kepentingan bersama dan mendesak dengan berpijak pada prasarana (uraian singkat mengenai suatu masalah dari sudut pandang tertentu) serta tanggapan-tanggapan dan diskusi sehingga terumuskan suatu pemecahan yang akurat (Kamdhi, J.S, 2010). Setelah menganalisis permasalahan dan mendapatkan pemecahan masalah, selanjutnya dilakukan penyuluhan kepada warga. Selanjutnya dibuat kesepakatan mengenai waktu pelaksaan program.

b. Evaluasi Program

Evaluasi adalah mengenai pembuktian keberhasilan atau kegagalan suatu program (Bastian, I., 2007). Program yang sudah terlaksana selanjutnya akan dievaluasi apakah program tersebut dapat memecahkan permasalahan pemasaran atau belum.

c. Pembuat Laporan

Laporan berisi tentang hasil penyuluhan yang terkait dengan bagimana mengolah dan megelola sampah yang baik dengan prinsip 3R (Reduce, Reuse, Recycle). 


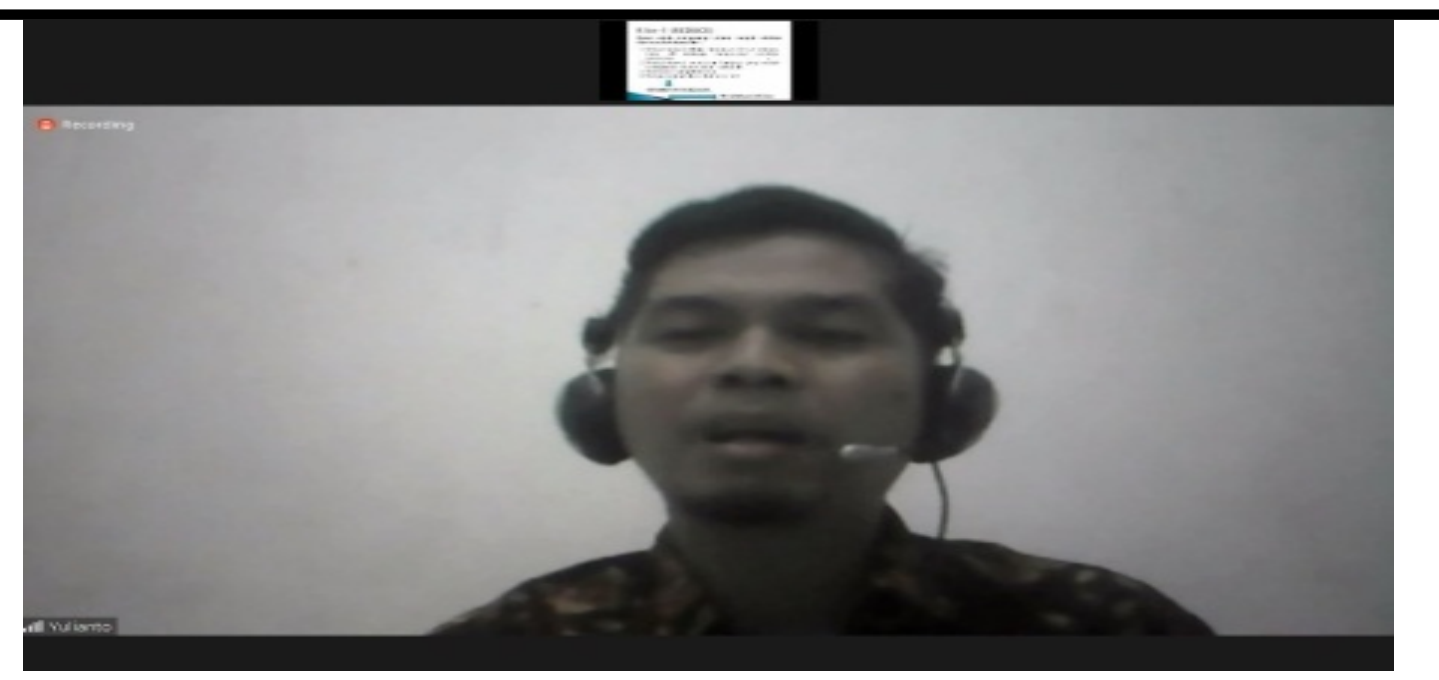

Gambar 1. Pemaparan Materi oleh salah satu Narasumber

Pada sesi ini membahas suatu masalah yang menyangkut kepentingan bersama dan mendesak dengan berpijak pada prasarana dan diskusi mengenai Bank Sampah Sri Rejeki.

\section{HASIL DAN PEMBAHASAN \\ 1. Tahap Persiapan}

a. Persiapan pelaksanaan Kegiatan, antara lain melakukan komunikasi awal tentang rencana kegiatan, melakukan perijinan tempat, survey awal dan melakukan rapat koordinasi tim pelaksana.

b. Melakukan diskusi dengan mitra terkait program yang akan di laksanakan.

c. Diskusi tentang Partisipasi Pengurus Bank Sampah pada khususnya serta warga dan pengurus pusat bank sampah wilayah kecamatan

d. Menyusun rencana kegiatan penyuluhan dalam bentuk seminar, dilaksanakan pada tanggal 12 - 14 Juni 2020.

\section{Pelaksanaan Kegiatan}

a. Sebagian Anggota TIM PKM berkunjung kelokasi Bank Smpah.

b. Persiapan kebutuhan pendukung bagi kegiatan penyuluhan dan pendampingan diskusi dengan para peserta

c. Persiapan juga dilakkukan terhadap perangkat yang dibutuhkan.

d. Penyuluhan dalam bentuk seminar.

\section{Hasil dari Kegiatan}

a. Pengurus dan Anggota Bank Sampah mengerti dan memahami bagaimana pentingnya peran Bank Sampah dalam lingkungan dan bisa menjadi sumber penghasilan tambahan.

b. Pengurus dan Anggota Bank Sampah Mengerti dan Memahami Bagaimana Memanajemen usaha bank sampah yang produktif dan efektif

c. Pengurus dan Anggota Bank Sampah Memahami dan mengerti bagaimana mengolah dan mengelola sampah yang baik dengan prinsip 3R (Reduce, Reuse, Recycle). 


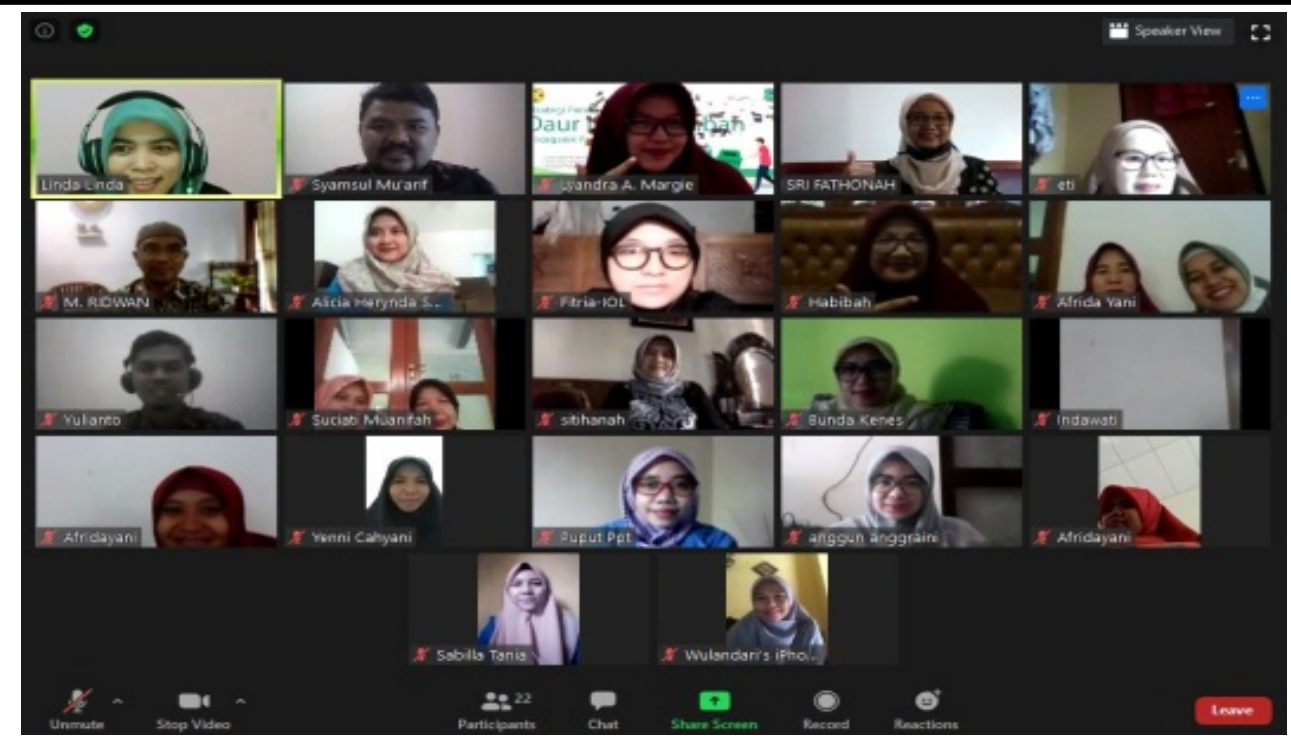

Gambar 2. Foto Bersama Para Peserta PKM

\section{KESIMPULAN DAN SARAN}

\section{Kesimpulan}

Dari hasil kegiatan Pengabdian Kepada Masyarakat ini dapat disimpulkan:

1. Untuk bisa menghasilkan nilai ekonomis suatu barang, dapat berupa apapun termasuk sampah daur ulang khususnya anorganik

2. Dengan mulai maraknya pengetahuan masyarakat terkait pengolahan sampah menjadikan masyarakat berusaha mengelolah sampah menjadi suatu produk yang bernilai tinggi dengan prinsip 3R (Reduce, Reuse, Recycle).

3. Sebagian Masyarakat masih mengembangkan usaha kreatif mereka secara individu dan tradisional sehingga sulit untuk berkembang menjadi industri yang terintegrasi dan aplikatif

\section{Saran}

Mengingat besarnya manfaat dari kegiatan Pengabdian Kepada Masyarakat ini, maka saran yang diberikan adalah:

1. Memperlebar pengetahuan dan pemahaman tentang pengelolaan sampah yang baik dengan prinsip 3R (Reduce, Reuse, Recycle) ke wilayah yang lebih luas

2. Membuat tindak lanjut dari hasil penyuluhan ini untuk melihat progress dan hasil yang sudah dilakukan

3. Mengadakan lanjutan penyuluhan kembali dari program penyuluhan sebelumnya.

\section{Ucapan Terima Kasih}

Penulis mengucapkan terima kasih yang tak terhingga kepada ketua Yayasan Sasmita Jaya, LPPM Universitas Pamulang, dan para warga di Perumahan Sarua Permai Jl. Borobudur 1 C 26 No. 5 RT. 01 RW. 04 Kelurahan Benda Baru Kecamatan Pamulang Kota Tangerang Selatan dan pada khususnya adalah pengurus dan anggota Bank Sampah Sri Rejekiyang telah banyak memberikan dukungan dalam kegiatan PKM ini. 


\section{DAFTAR PUSTAKA}

Aminudin. (2013). Manfaat Daur Ulang Sampah. http://www.aminudin .com/2013/06/manfaat-daur-ulang-sampah.html . Diakses pada tanggal 29 september 2019.

Anggani, Sri. (2014). Kreasi Daur Ulang. Jakarta: Gramedia Pustaka Utama.

Anonym. (2012). Pengolahan Sampah. http://www.isomwebs.net . Diakses pada tanggal 29 September 2019

Eka Utami. (2013). "Buku Panduan Sistem Bank Sampah \& 10 Kisah Sukses", Yayasan Unilever Indonesia.

F., Firdha. (2010). Daur Ulang Sampah. http://firdhaf08.student.ipb.ac.id/2010/06/19/daurulang-sampah.html. Diakses pada tanggal 29 september 2019

https:/m3penyuluhanfapetub2017bloh.wordpress.com

Kementrian Pekerjaan Umum Badan Penelitian dan Pengembangan Pusat Penelitian dan Pengembangan Pemukiman. "Modul Pengelolaan Sampah Berbasis 3R", Bandung. 2010.

Kban, Jabat. (2012). Bisnis Kreatif Kerajinan Daur Ulang Limbah. Yogyakarta: Majalah Bisnis UKM

Qardhul Hasan: Media Pengabdian kepada Masyarakat p-ISSN 2442-3726 e-ISSN 25501143 diakses pada tanggal 29 september 2019

Ishariatiz, (2012), "Bank Sampah";Yogyakarta

Faizah. (2008). Pengelolaan sampah berbasis masyarakat, Semarang; Universitas Diponegoro 